\title{
Sinop İlinin Turizm Odaklı Gelişimine Dair Turist Rehberlerinin Rolleri ve Görüşleri"
}

\section{The Roles and Views of Tourist Guides on the Tourism-Oriented Development of Sinop Province}

\author{
Dr. Öğr. Üyesi Gül ERKOL BAYRAM \\ Sinop Üniversitesi, Turizm İşletmeciliği ve Otelcilik Yüksekokulu, Türkiye \\ Sinop University, School of Tourism and Hotel Management, Turkey
}

E-Mail: gulerkol@windowslive.com

$\ddot{O} z$

\begin{abstract}
Amaç ve Önem: Turist rehberleri turistlerin destinasyona yönelik algısını yönlendirmekte, kültürel ve sosyal arabulucu olarak turistlerin tekrar ziyaretlerini etkilemektedir. Özellikle gelişmekte olan destinasyonlar için turist rehberleri önemli bir işleve sahiptir. Destinasyonların kalkınmasında, pazarlanmasında ve tanıtımında kayda değer bir konuma ve etkiye sahip olan turist rehberlerinin bölgenin sosyal, kültürel ve ekonomik gelişimine dair olumlu etkilerinin bulunduğu bilinmektedir. Sinop son yıllarda farklı turizm türleri ile tanınan ve gelişen bir turizm kenti olarak kabul edilmekte, günübirlik ya da kısa süreli turistik gruplar tarafindan ziyaret edilmektedir. Çalışma Sinop ilinde hizmet veren veya grubu ile ziyaret eden turist rehberlerinin Sinop turizminin gelişimindeki rolünü, etkisini, Sinop ilinin tanıtımına dair katkılarını ve şehrin mevcut turizm potansiyeline dair görüşlerini, önerilerini tespit etmeyi amaçlamaktadır. Araştırma; Sinop destinasyonu gibi kültür turizminde hızlı gelişim gösteren bir destinasyonun turist rehberlerinin bakış açısıyla değerlendirilmesi ve geleceğe dair önemli tespitler yapılması açısından önemli görülmektedir.
\end{abstract}

Yöntem: Bu çalışmada sosyal bilimlerin en sık kullanılan yöntemlerinden biri olan nitel araștırma yöntemi kullanılarak; araştırmanın amaç ve önemine istinaden mülakat tekniğinden yararlanılmıştır. Araştırmada amaçlı örnekleme yöntemlerinden biri olan benzeşik örnekleme yöntemi kullanılmıştır. Mülakatta kullanılan sorular; Látková ve arkadaşlarının (2017) araştırmasından yararlanılarak konu ve destinasyona uyarlanmıştır. Görüşmeler 15 rehber ile yüzyüze ve çevrimiçi olarak gerçekleștirilmiştir. Mülakatlardan boş olan ya da ilgisiz cevaplandırılan görüşmeler sebebiyle 13 mülakat değerlendirmeye tabi tutulmuştur. Görüşmeler kapsamında elde edilen veriler Strauss ve Corbin'nin (1990) kodlama ve kategorilere ayırma modeli ile ifade edilerek; araştırmacı tarafından birbirine benzerlik gösteren ifadeler benzer kategorilere ayrılmıştır.

Bulgular: Araştırmaya katılan turist rehberlerinin büyük bir kısmı turist rehberinin ülkeyi tanıtma, kültürel kaynakları gelecek nesillere aktarma, turistlere doğru bilgi verme gibi işlevlerinin olduğunu ifade etmiş̧lerdir. Ayrıca turist rehberleri destinasyona yönelik olumlu imajın sağlanmasına kendilerine büyük görevler düștüğüne inanmaktadır. Katılımcılar; kamu kurumları ile iş birliği içinde olmaları ve Sinop ilinin turizme yönelik gelişiminde etkin bir rol oynamaları ve söz sahibi olmaları gerektiğine inanmakta ve özellikle turistlerin ihtiyaç ve beklentilerini analiz etmesi açısından aracı bir rol oynadıklarını düşünmektedirler. Araştırmaya katılan turist rehberleri grubuyla ziyaret ettikleri destinasyonlarda bazı alt yapı ve üst yapı sorunlarının varlığına değinmișlerdir. Katılımcılar Sinop'un turistler için cazip bir destinasyon olduğu, ancak belli başlı çekiciliklerin dışında farklı nitelikleriyle de tanıtılması gerekliliğini ifade etmişlerdir. Turist rehberleri; Sinop ilinin hem özel sektör hem de kamu kurumlarının işbirliği ile kalkınabileceğini düşünmektedir.

Özgünlük/Bilimsel Katkı: Araştırma Sinop ili gibi turizmde hızlı bir gelişim gösteren kentin kalkınmasını incelemiştir. Bu incelemeyi de turist rehberleri perspektifinden gerçekleştirmeye

Atıf için (for cited); Erkol Bayram, G. (2019). Sinop İlinin Turizm Odaklı Gelişimine Dair Turist Rehberlerinin Rolleri ve Görüşleri, Turist Rehberliği Dergisi, 2(2), 57-71.

* Bu çalışma II. Turizm Rehberliği Kongresi'nde sunulmuş olan özet bildirinin tam metin halidir. 
Turist Rehberliği Dergisi (TURED) \& Yıl. 2019, Cilt. 2, Sayı. 2

Journal of Tour Guiding (JOTOG) \& Year. 2019, Volume. 2, Issue. 2

çalışmıştır. Literatürde az rastlanan turizm ve bölgesel kalkınma ilişkisine farklı bir bakış açısı sunması bakımından özgün bir değere sahip olduğu öngörülmektedir.

Anahtar Kelimeler: Bölgesel kalkınma, sürdürülebilir kalkınma, turizm rehberliği, Sinop.

Makale Türü: Araştırma makalesi

\begin{abstract}
Purpose and Importance: Tourist guides directs to tourists' perception to destinations and influence the revisits of tourists as cultural and social mediators. In particular, tourist guides have an important function for developing destinations. It is known that tourist guides, which have a significant position and influence in the development, marketing and promotion of destinations, have positive effects on the social, cultural and economic development of the region. In recent years, Sinop is recognized as a thriving tourism city with different types of tourism and is visited by daily or short-term touristic groups. The aim of this study is to determine the role, impact of tourist guides in Sinop province or their group, their contribution to the promotion of Sinop province and their opinions and suggestions about the current tourism potential of the city. Research, being evaluated to a destination such as Sinop destination developing rapidly in cultural tourism, is considered important in terms of evaluating from the point of view of tourist guides and making important determinations about the future.
\end{abstract}

Methodology: In this study, one of the most commonly used methods of social sciences, qualitative research method was used. Interview form was used for the purpose and importance of the research. In the study, one of the purposeful sampling methods, which is the homogeneous sampling method, was used. The questions used in the interview were adapted to the topic and destination using the survey of Látková et al. (2017). Interviews were conducted face-to-face and online with 15 guides. 13 interviews were evaluated due to the interviews that were empty or unrelated to the interviews. The results were analyzed according to qualitative research methods.

Findings: The majority of the tourist guides who participated in the research stated that the tourist guide has the functions of introducing the country, transferring cultural resources to future generations and providing accurate information to tourists. In addition, tourist guides believe that they have a great responsibility to provide a positive image for the destination. Participants; They believe that they should cooperate with public institutions and play an active role and have a say in the development of Sinop for tourism and think that they play an intermediary role especially in terms of analyzing the needs and expectations of tourists. They also mentioned the existence of some infrastructure and superstructure problems in the destinations they visited with the group of tourist guides participating in the research. The participants stated that Sinop is an attractive destination for tourists but it should be introduced with different qualities besides the main attractions. Tourist guides believes that Sinop province can be developed with the cooperation of both private sector and public institutions.

Originality/Value: The study examined the development of a shining city in tourism, such as the province of Sinop. It is anticipated to have a unique value in terms of providing a different perspective on the relationship between tourism and regional development, which is rare in the literature.

Keywords: Regional development, sustainable development, tourism guidance, Sinop.

Paper Type: Research article

Giriş

Turizm sektöründe özellikle önemli olan kültürlerarası etkileşimlerde özel bir rol oynayan turist rehberi; ziyaret edilen alanlar, fotoğraflanan yerler ve karşılaşılan insanlar hakkında bilgi ve hikâyeler sağlamakta ve tur otobüslerinin camlarının dışındaki sessiz panoramaya bir yorum kazandirmaktadır (Leclerc ve Martin, 2004: 182). Turist rehberi, ziyaretçilerin, işverenlerin ve yerel toplulukların ihtiyaçlarını karşılamak için, turizm hizmeti sağlayıcıları gibi geniş sorumluluklara sahiptir (Ham ve Weiler, 2002: 54). Dünya üzerinde and Views of Tourist Guides on the Tourism-Oriented Development of Sinop Province 


\section{IIIII)}

Turist Rehberliği Dergisi (TURED) \& Yıl. 2019, Cilt. 2, Sayı. 2

Journal of Tour Guiding (JOTOG) \& Year. 2019, Volume. 2, Issue. 2

önemi yadsınamayacak düzeyde olan turist rehberi, Türkiye turizminde de çok önemli bir işlevi yerine getirmektedir. Ülkemizdeki turist rehberlerinin 1890'lardan günümüze kadar ülkenin tanıtımı; imajı; temsili gibi ciddi hususlarda büyük sorumlulukları söz konusudur (Çokişler ve Öter, 2014: 196).

Turist rehberi sergilemiş olduğu davranışlar neticesinde turiste, toplum ve ülke hakkında fikir ve bilgi veren bir durum içerisinde yer almaktadır. Nitekim başka bir ülkeye gelen turist grubu; yanlarında kitap, harita, broşür gibi statik rehberler bulundurabilse de bu argümanlar onlar adına yeterli olmamaktadır. Nihayetinde gidilen ülkenin dilinin, gelenek ve göreneklerinin bilinmemesi ve bu bilinmeme durumunun korku ve tedirginliğe mahal vermesi gibi nedenler, turistlere rehberlik edecek bir rehbere ihtiyaç duyulmasını ortaya çıkarmaktadır. Oluşan bu ihtiyacın giderilmesinin yanında turist rehberi, turistlere ülke ve toplum nezdinde daha iyi tanıtma olanağı sunan, turistlerin sahip olduğu olası yanlış ve hatalı bilgilerin düzeltilmesini sağlayan kişi konumundadır. Dolayısıyla turist rehberinin önemini, ülkesini ve toplumunu temsil eden gönüllü bir turizm elçisi olmasıyla vurgulamak mümkündür.

Sinop ili birbirinden farklı turistik çekiciliklere sahip olmanın yanında; dünyada eşine az rastlanır doğal limanlara, sahillere ve tabiat parklarına sahiptir. Turizmin değişen yönüyle Sinop şehri daha fazla doğa temelli turizm faaliyetleriyle ilgilenen turistleri çekmektedir. Özellikle yazın deniz turizmi, sonbahar ve baharda da ekoturizm, trekking, sportif olta balıkçılığı gibi aktivitelerin ve turizm türlerinin yapılıyor olması; turizm sezonunun tüm yıla yayılmasını sağlamaktadır. Turizm plan ve politikalarının bu bağlamda geliştirilmesi ile bu durumun artarak devam edeceği umulmaktadır. Gelişimin bir diğer ayağı ise; turizm paydaşlarının rol ve sorumluluklarını yeri getirmesidir. Bu turizm paydaşlarından biri olan turist rehberleri turistlerin algısını oluşturan, yönlendiren, tura çıktıkları seyahat acentesinden ve destinasyondan memnun olmalarını kolaylaştıran kişilerdir. Araştırmanın konusu olan Sinop destinasyonunun kalkınmasında turist rehberlerinin rolleri ve görüșlerinin belirlenmesi; Sinop ilinin mevcut durumunun tespiti ve değerlendirilmesi açısından önemli görülmektedir.

\section{Literatür İncelemesi}

Türk Dil Kurumuna göre kalkınma; "ekonomide manevi değerler, politik ve sosyal görüş, bireylerin tüketim kalıpları, davranışları, yaşam biçimleri gibi önemli olaylarda değişimle ilgili olan toplumsal ve kuramsal dönüşüme yol açabilen büyüme" olarak tanımlanmaktadır. Genel olarak kalkınmayı değişim, ilerleyiş, değişim gibi kavramlara sebep olabilecek büyümeler olarak tanımlanabilmektedir. Bu kapsamda kalkınma kavramının büyüme, gelişime, ilerleme, yükselme gibi konularla yakın bir ilişkisi olduğunu ifade etmek mümkündür. Ayrıca kalkınma uzun süreli ve yapısal değişiklikleri de ifade etmesi sebebiyle toplumun büyük bir kesimini ilgilendirmektedir. Kalkınma; bölgenin gelişmemiş ve geri kalmış kısımlarını güçlendirerek; geliştiren ve yükselten bir kavramdır (Kaypak, 2012: 14). Han ve Kaya (2008) kalkınmanın katkılarını aşağıdaki gibi tanımlamaktadır;

- Kişi başına düşen milli gelirde artış sağlar.

- Üretim faktörlerinde nitelik ve nicelik olarak bir değişim oluşturur.

- Üretime ve hizmete dayalı sektörlerin milli gelirdeki payında artış sağlar.

Gelişim ve ilerleme temelli yaklaşım göz ardı edilmeden, gelecek nesillerin kullanabilecekleri kaynakları düşünerek; kaynakların çevreye zarar vermeden kullanılmasına sürdürülebilir kalkınma denilmektedir ve günümüz kalkınma yaklaşımlarının benimsediği temel felsefelerden biri de sürdürülebilir temelli kalkınmadır (Emeksiz, 2007; Çubuk, 1996). Başarılı kalkınma planları "sürdürülebilir büyüme" ve “ sürdürülebilir ekonomi” gibi kavramları bünyelerinde barındırmaktadır. Ancak sürdürülebilirlik pek çok konunun bütünleşik 
korunmasıyla ilgilidir. Bunlar arasında yer alan; tarım, enerji, doğal kaynaklar, kırsal alanların kalkınması, planlı kentleşme ve ulaşım kavramları sürdürülebilirlik kavramını büyük oranda benimseyen sektörlerdendir (Y1kmaz, 2011: 5).

Sürdürülebilir kalkınmanın en çok kullanıldığı sektörlerden biri de turizmdir. Turizm ekonomik faaliyetler içinde hızla gelişen ve yükselen, gelişmiş bölgelerin güçlü ekonomilerinde devamlılık sağlarken; gelişmekte olan ülkelerin büyüme ve kalkınmalarına katkı sağlayan, gelişmemiş ülkeler için de umut veren, en önemli ve en az maliyetli ekonomik büyüme aracı olarak görülmektedir. Özellikle Türkiye gibi gelişmekte olan bölgeler açısından düşünüldügünde turizm ve kalkınma birbirinden ayrılmaz durumdadır. Yeni çekim merkezlerinin turizme kazandırılmasıyla farklı ülke ve bölgelerden yerli ve yabancı turist gelecek, bölgede ihtiyaç duyulan istihdam kaynakları arttırılacak, yerel halk ekonomik, kültürel ve sosyolojik açıdan bir değişim yaşayacaktır (Erkol Bayram, Bayram ve Altunoz, 2016).

Turizm ve kalkınma ilişkisini inceleyen çalışmaların sürdürülebilirlik, kalkınmada etkili olan aktörler ve kalkınmanın bölgeye ekonomik ve sosyal katkıları üzerinde durdukları tespit edilmiştir. Küçük ve Güneş'in (2013) çalışmalarında turizm ve yerel kalkınma ilişkisi ele alınarak; turizmdeki farklı paydaşların kalkınmadaki etkisi incelenmiştir. Turizm sisteminde yer alan yerel halk ve konaklama işletmesi personeli turizmin kalkınmaya etki etmesi için sürdürülebilirlik, eğitim, tanıtım ve altyapı imkânları ile daha çok ilişki içinde olması gerektiğine inanmaktadırlar. Künü ve Hopoğlu (2016) ise turizm içinde kalkınmanın bir araç değil, bir süreç olduğunu vurgulamışlardır. Her bölgenin turizmle gelişebileceği fikrini de eleştiren araştırmada salt turizmle kalkınmanın mümkün olmayacağını tarım, gıda, eğitim, sanayi ve daha farklı sektörlerin uyumuyla gerçekleşebileceğini ifade etmekte ve turizmde yer alan tüm paydaşların kusursuz uyumu ile turizme dayalı kalkınmanın mümkün olabileceğini savunmaktadırlar. Tekbalkan (2017) ise Samsun kalkınmasında turizmin etkisini işletme sahipleri açısından değerlendirmiștir. İșletmeciler bölgenin hak ettiği turisti ağırlayamamasına karşın; turizmin bölgesel kalkınmaya olumlu şekilde etki edeceği, kalkınmanın nitelikli personel, yeterli miktarda turistik tesis, bilinçli yerel halk ile mümkün olabileceği görüşündedir.

Son yıllarda yönü ve hedefleri farklılaşan turizmde, turizm faaliyetleri ile turizme yönelik tutum ve algının da büyük farklılaştığı görülmektedir. Klasik deniz turizmi aktivelerine ek olarak doğaya dayalı turizm faaliyetleri, kültüre dayalı turizm faaliyetleri, eğitim ve iş amaçlı turizm faaliyetleri olarak çeşitlendirilen turizmin bölgesel gelişime anlamlı katkılar sağladığını söylemek mümkündür (Keskin ve Cansız, 2010). Özellikle bölgeler arası dengesizliğin giderilmesi, ekonomik, sosyal ve kültürel gelişimden ülkenin tamamının etkilenmesi arzu edilen bir durumdur ancak bu istek o bölgenin kalkınma potansiyeliyle de yakından alakalıdır (Şanlı ve Ekşi, 2005).

Turizmin hemen hemen tüm iş kollarının belli başlı yükümlülükleri bulunmaktadır. Önbüro departmanında çalışan resepsiyonist; turistin konaklama süresince mutlu, huzurlu, keyif alabildiği ve bu huzuru tavsiye niyetine dönüştürebildiği bir tatil geçirmesini kendisine görev edinmiş̧tir. Bir balık restoranında çalışan komi ise; yemek yemeyle beraber keyif almayı da hedefleyen turiste; kararsız bir turistin hangi ürünü seçmesi gerektiğine karar vermesine yardımcı olmakla kalmayıp, kaliteli servis hizmeti ve güler yüzüyle turizmin hizmet boyutunun markası olacaktır. Turist rehberi ise sahip olduğu sayısız rolüyle bağlı olduğu bölgenin ve ülkenin elçisi, temsilcisi olacaktır. Turist rehberi sadece bilgi aktarmakla kalmamakta; aynı zamanda o bölgenin gelişimine, büyümesine ilerlemesine anlamlı katkılar da sağlamaktadır.

Turist rehberi turistlerin ülkeye gelişinden ayrılışına değin turistin yanında yer alan, o ülke ya da bölgeye yönelik algıyı güçlendiren, tur sırasında turistlere bölgeyle ilgili gerekli bilgi veren, gözlem ve deneyimlerini paylaşan bu paylaşımlarını mümkün olduğunca turistlerin 


\section{IIIII)}

Turist Rehberliği Dergisi (TURED) \& Y11. 2019, Cilt. 2, Sayı. 2

Journal of Tour Guiding (JOTOG) \& Year. 2019, Volume. 2, Issue. 2

zihninde yer edecek şekilde gerçekleştiren farklı rollere sahip olan kişi olarak tanımlanmaktadır (Aktaş ve Batman, 2010: 379). Bağlı olduğu ülkeye ve grubunun ziyaret ettiği bölgeye dair bilgi aktaran ve uzmanlık alanı olan bölgenin tarihi, kültürü, doğası hakkında gerekli bilgi ve deneyimlerini aktararak turistlerin o bölgeyle ilgili gerçekçi ve net bilgiye sahip olmasını sağlayan, tur sırasında turistlere yardımcı olan ve onlarla ilgilenen, kültür ve turizm bakanlığı tarafindan verilen profesyonel turist rehberi ruhsatnamesine sahip kişiye turist rehberi denilmektedir (Köroğlu, 2013: 92).

6326 say1lı Turist Rehberliği Meslek Kanunu'na (2012: madde 2) göre turist rehberi “6326 Sayılı Turist Rehberliği Meslek Kanunu'nun hükümleri uyarınca mesleğe kabul edilerek seyahat acentalığı faaliyeti niteliğinde olmamak kaydıyla kişi veya grup hâlindeki yerli veya yabancı turistlerin gezi öncesinde seçmiş oldukları dil kullanılarak ülkenin kültür, turizm, tarih, çevre, doğa, sosyal veya benzeri değerleri ile varlıklarının kültür ve turizm politikaları doğrultusunda tanıtılarak gezdirilmesi veya seyahat acentaları tarafindan düzenlenen turların gezi programının seyahat acentasının yazılı belgelerinde tanımladığı ve tüketiciye satıldığı şekilde yürütülüp acenta adına yönetilmesi hak ve yetkisine sahip olan gerçek kişis” olarak tanımlanmaktadır.

Erkol Bayram (2017)'a göre turist rehberi; tur sırasında turistlere pek çok konuyla ilgili yardımcı olan, ülkesine ve bölgesine ait tarihi, doğal, kültürel konularla ilgili en doğru ve etkili biçimde aktaran, yerel halk ve turistlerle iletişim sürecini başlatan ve güçlendiren, soyut ve somut mirasın gelişmesinde büyük role sahip olan, turistlere kültürel ve doğal kaynakların korunmasında gerekli hassasiyet ve duyarlılı̆̆ aşılayan, olumlu imajın gelişmesine ve güçlenmesine büyük katkı sunan kişilere denilmektedir. Turist rehberi ayrıca; genellikle seyahat acentası tarafından gerçekleştirilen turlarda çoğu kez seyahat acentası adına turlarda yer alarak turistlerin tur boyunca yanlarında olmakta, onlarla pek çok konuyla ilgili ilgilenmekte, çevirmenlik, kültür simsarlığı, öğretmenlik, arabuluculuk, liderlik gibi pek çok görevi başarıyla üstlenmektedir.

Turist rehberleri turizm sektörü için farklı işlevlere sahip olmasıyla sebebiyle oldukça önemlidir. Örneğin; Konaklama sırasında memnun olmamış bir turistin o şehirden mutlu ayrılmasının sebebi bir turist rehberi olabilir, ya da Tur sırasında uğradıkları restoranda beklediği hizmeti bulamayan bir turistin sorunlarını rehber bir şekilde çözebilir. Şenel (2011: 12-14) turist rehberlerinin turizm sektöründeki önemine dikkat çekerek aşağıdaki maddelerle açıklamıştır;

- Turist rehberi ülkenin tanıtımında büyük role sahiptir.

- Turistlerin bir bölge ya da ülkeden memnun ayrılmasındaki sebeplerden biri de; rehberi tarafindan gerçekleştirilen doğru ve eksiksiz bilgi aktarımıdır.

- Turist rehberi bölgenin doğal, kültürel ve tarihi özelliklerini anlatmanın yanında; bölgenin, ülkenin politikası, sosyal yapısı, etnik ve dini özellikleri gibi bilgileriyle ilgili de doğru ve net bilgiler vermelidir.

- Yerel halk ile turist arasında aracı ve kültürleri bağlayıcıdır.

- Turistlerle birebir ilişki içindedir ve bu nedenle ülkesinin temsil etmesi sebebiyle oldukça önemli bir konumdadır.

- Turizmde satışların büyük bir kısmını o bölgeyi ziyaret eden turistlerin geri bildirimleri etkilemektedir. Turistlerin turla ilgili olumlu geri bildirimleri turist rehberini büyük oranda etkileyecektir. 


\section{IIIII)}

Turist Rehberliği Dergisi (TURED) \& Y11. 2019, Cilt. 2, Sayı. 2

Journal of Tour Guiding (JOTOG) \& Year. 2019, Volume. 2, Issue. 2

- Turist rehberleri turistlerin algisını şekillendirmektedir ve bu durum turizm sisteminde yer alan tüm paydaşların pazarlama faaliyetlerine etki etmektedir.

- Tur sırasında gezilen, görülen bölgelerin aktarıcısı, yorumlayıcısı ve özetleyicisidir. Bölgeyle ilgili önemli ya da ilgi çekici detaylara yönelik bilgi verir ve turistlerin ziyaret ettikleri bölgeyi tekrardan ziyaret etmelerine vesile olur.

- Seyahat acentalarına turla ilgili bilgi verir, turistlerle ilgili önemli gördüğü konuları aktarır ve gelecek turlarda acentanın daha sağlam adımlarla turunu gerçekleştirmesine imkân sunar.

Turist rehberi pek çok konuyu ve uzmanlık alanını içinde barındıran bir meslek grubudur. Endişeli bir turist gördüğünde bir psikolog, kültürleri merak eden bir turist gördüğünde antropolog, hayatında görmediği antik kent kalmamış ve ilgi alanı Lahitler olan bir turist gördügünde ise arkeolog olmalıdır. Bunlarla birlikte turist rehberi genel hatlarıly; tur sırasında turun sorumluluğunu üstlenmeli, belki de hayatında hiç müze gezmemiş birine anlatır gibi iyi bir eğitimci olmalı, turistler kendi evine gelmiş gibi güler yüzlü, misafirperver, hoşgörülü, benzersiz bir ev sahibi olmalı ve bu becerileri nerede ve ne zaman kullanacağını gayet iyi bilmeli ve farkına varmalıdır (Pond, 1993; Ap ve Wong, 2001: 552 akt. Ak, Kargiglioglu ve Bayram, 2019: 24).

Turist rehberlerinin destinasyonların gelişimi, bölgenin kalkınması, ülkenin imajının olumlu yönde gelişmesine dair olumlu katkıları olduğu bilinmektedir. Eker ve Zengin (2016) turist rehberlerinin elçi rolüne vurgu yaparak; turistelerin seyahatlerinden mutlu ayrılmaları, kaliteli bir tatil deneyimine sahip olmaları, ziyaret ettiği bölgeye ve ülkeye yönelik olumlu bir bakış açısına sahip olması ve bu kapsamda turizmden elde edilen gelirin artması ve rekabet üstünlüğü sağlanması gibi konulara katkı sağladıklarını ifade etmişlerdir. Huang ve arkadaşları çalışmalarında turist rehberlerinin bölgesel kalkınmada etkin bir role sahip olduğunu ve tur deneyimlerinin bölgesel ya da ülkesel imajı olumlu şekilde etkileyebileceğini ifade etmiştir. Yıldız, Kuşluvan ve Şenyurt (1997) turist rehberlerinin turistler için vazgeçilmez bir kaynak olduğunu, uluslararası alanda büyük bir role sahip olduğunu, sunduğu hizmet ile ülkesini pek çok destinasyonu rekabet edebilir düzeye ulaştırabileceğini dile getirmiştir. Hughes (1991) turistlerin daha önce deneyimlemedikleri bir ortamda turist rehberleri aracılığıyla o bölgede evlerindeymiş gibi hissetmelerine odaklanmakta ve yerel halk, destinasyon, bölge hakkında olumlu izlenim oluşturmalarında turist rehberlerine büyük sorumluluklar düştüğünü ifade etmektedir.

\section{Yöntem}

Araştırmanın amacı, Sinop ilinin turizme yönelik kalkınmasında turist rehberlerinin rolleri ve görüşlerini tespit etmek, turizmin gelişimini dair önerilerini belirlemeye çalışmaktır. Araştırma amacına istinaden Sinop ilinde aktif olarak rehberlik yapan ve Sinop iline gerçekleştirilen turlarda görev alan turist rehberlerine mülakatlar gerçekleştirilmiştir. Araştırma; Sinop destinasyonu gibi kültür turizminde hızlı gelişim gösteren bir destinasyonun turist rehberlerinin bakış açısıyla değerlendirilmesi ve geleceğe dair önemli tespitler yapılması açısından önemli görülmektedir.

Bu çalışmada sosyal bilimlerin en sık kullanılan yöntemlerinden biri olan nitel araştırma yöntemi kullanılarak; araştırmanın amaç ve önemine istinaden mülakat tekniğinden yararlanılmıştır. Araştırmada amaçlı örnekleme yöntemlerinden biri olan benzeşik örnekleme yöntemi kullanılmıştır. Mülakatta kullanılan sorular; Látková ve arkadaşlarının (2017) araştırmasından yararlanılarak konu ve destinasyona uyarlanmıştır. Görüşmeler 15 rehber ile yüz yüze ve çevrimiçi olarak gerçekleştirilmiştir. Mülakatlardan boş olan ya da ilgisiz 
Turist Rehberliği Dergisi (TURED) \& Yıl. 2019, Cilt. 2, Sayı. 2

Journal of Tour Guiding (JOTOG) \& Year. 2019, Volume. 2, Issue. 2

cevaplandırılan görüşmeler sebebiyle 13 mülakat değerlendirmeye tabi tutulmuştur. Görüşmeler kapsaminda elde edilen veriler Strauss ve Corbin'nin (1990) kodlama ve kategorilere ayırma modeli ile ifade edilerek; araştırmacı tarafindan birbirine benzerlik gösteren ifadeler benzer kategorilere ayrılmıştır. Çalışmada nitel yöntemin kullanılmasının temel amacı; belli bir soruya cevap aramaktan ziyade; kişilerin bir konuyla ilgili neler düşündüğünü, nasıl algıladıklarını tespit etmektedir (Türnüklü, 2000: 3). Görüşme tekniğinde araştırma konusuna dâhil olan kişiler tespit edilerek, görüşmeler yapılmaktadır. Kayıt cihazı ya da not alma yöntemi ile veriler kayıt altına alınmaktadır. Elde edilen veriler toparlanmakta ve incelenmektedir (Yıldırım ve Şimşek, 2008).

\subsection{Veri Toplama Süreci ve Analiz Yöntemi}

Araştırmada amaçlı örnekleme yöntemlerinden benzeşik örnekleme yöntemi kullanılmıştır. Benzeşik örnekleme yöntemi evren içinden araştırmaya uygun olan bir grubun seçilerek çalışmanın bu alt grup ile gerçekleştirilme sürecini ifade etmektedir. Nitel araştırma yöntemlerinde güvenirliği sağlamak için çalışmanın benzer sonuçların benzer katılımcılarla tekrarlandığında aynı sonucu vermesi istenmektedir. Bunun içinde araştırma yöntemlerinin ayrıntılı tanıtımı, literatür incelemesi, verilerin raporlanması ve sonuçlara nasıl ulaşılabildiğinin açıklanması gibi yöntemler kullanılmaktadır.

Araştırma kapsamında 15.03.2019-20.04.2019 tarihleri arasında turist rehberleri ile mülakatlar gerçekleştirilerek, Sinop ilinin turizme yönelik gelişmesindeki rolleri- rol ve sorumlulukları ile önerileri tespit edilmeye çalışılmış- veriler nitel araştırma yöntemlerine uygun analiz edilmiştir. Mülakatta kullanılan sorular, Látková ve arkadaşlarının (2017) araştırmasından yararlanılarak konu ve destinasyona uyarlanmıştır. Görüşmeler 15 rehber ile yüzyüze ve çevrimiçi olarak gerçekleştirilmiştir. Mülakatlardan boş olan ya da ilgisiz cevaplandırılan görüşmeler sebebiyle 13 mülakat değerlendirmeye tabi tutulmuştur.

Tablo 1: Araştırma Kapsamında Rehberlere Yöneltilen Sorular

\begin{tabular}{|l|}
\hline \multicolumn{1}{|c|}{ A - Demografik ve Mesleki Özelliklere İlişkin Sorular } \\
\hline 1 - Yaşınız \\
\hline 2 - Cinsiyet \\
\hline 3 - Eğitim Düzeyiniz \\
\hline 4 - Ruhsatname Tipiniz - Turist Rehberlerinin Rol ve Sorumlulukları \\
\hline \multicolumn{1}{|c|}{} \\
\hline $\begin{array}{l}\text { 1- Bir turist rehberi olarak; turizme yönelik kalkınmayı arttırmak adına rol ve sorumluklarınız } \\
\text { nelerdir? }\end{array}$ \\
\hline $\begin{array}{l}\text { 2- Sinop’ta turizm işletmelerinin gelişimi, çevresel kaynakların korunması, yerel halk ve kültüre olan } \\
\text { saygının arttırılması, destinasyon ekonomisinin geliştirilmesi, turizmle gelişimin sağlanması için bir } \\
\text { turist rehberi neler yapabilir? }\end{array}$ \\
\hline \multicolumn{1}{c|}{ C - Sinop İlinin Turizm Odaklı Gelişiminde Zorluklar-Mevcut Durum ve Öneriler } \\
\hline $\begin{array}{l}\text { 1- Tur sırasında; Turist rehberlerinin turistik bölgelerde yaşadığı zorluklar ya da sorunlar nelerdir? } \\
\text { Bu sorunların turistlerin memnuniyetine etkisi ne düzeydedir? }\end{array}$ \\
\hline $\begin{array}{l}\text { 2- Sinop ili turistlerin beklentilerine cevap verebilecek nitelikte bir destinasyon mudur? Turist de } \\
\text { bölgeye gerekli ekonomik katkıyı sağlıyor mu? }\end{array}$ \\
\hline $\begin{array}{l}\text { 3- Sinop ilinin turizmde gelişebilmesi adına Kamu kurumları ya da özel sektör bu konuda neler } \\
\text { yapmalıdır? }\end{array}$ \\
\hline
\end{tabular}

Erkol Bayram; Sinop İlinin Turizm Odaklı Gelişimine Dair Turist Rehberlerinin Rolleri ve Görüşleri / The Roles and Views of Tourist Guides on the Tourism-Oriented Development of Sinop Province 
Turist Rehberliği Dergisi (TURED) \& Yıl. 2019, Cilt. 2, Sayı. 2

Journal of Tour Guiding (JOTOG) \& Year. 2019, Volume. 2, Issue. 2

\section{Bulgular}

Turist rehberleriyle yapılan görüşmelerde katılımcılara ilk olarak demografik ve mesleki özelliklerine ilişkin sorulara yer verilmiş, sonrasında katılımcılara yöneltilen Sinop ilinin kalkınmasına yönelik sorulara ilişkin bulgular üzerinde durulmuştur.

\subsection{Katılımcıların Demografik ve Mesleki Özelliklerine İlişkin Bulgular}

Tablo 2. Araştırmaya Katılan Turist Rehberlerinin Demografik ve Mesleki Özellikleri

\begin{tabular}{|l|c|c|c|l|}
\hline \multicolumn{2}{|c|}{ Değişken } & \multicolumn{3}{|c|}{ Katılımcı Dağılımı } \\
\hline \multirow{4}{*}{ Yaş } & $18-25$ yaş & 2 & $\% 15,3$ & $\mathrm{~K} 1, \mathrm{~K} 2$ \\
\cline { 2 - 5 } & $26-35$ yaş & 3 & $\% 23,7$ & $\mathrm{~K} 3, \mathrm{~K} 4, \mathrm{~K} 13$ \\
\cline { 2 - 5 } & $36-45$ yaş & 5 & $\% 38,4$ & $\mathrm{~K} 5 \mathrm{~K} 6, \mathrm{~K} 9, \mathrm{~K} 10, \mathrm{~K} 12$ \\
\cline { 2 - 5 } & $46-55$ yaş & 3 & $\% 23,7$ & $\mathrm{~K} 7, \mathrm{~K} 8, \mathrm{~K} 11$ \\
\cline { 2 - 5 } & 55 yaş ve üzeri & - & - & - \\
\hline \multirow{2}{*}{ Cinsiyet } & Kadın & 4 & $\% 30,7$ & $\mathrm{~K} 1, \mathrm{~K} 2, \mathrm{~K} 6, \mathrm{~K} 13$ \\
\cline { 2 - 5 } & Erkek & 9 & $\% 69,2$ & $\mathrm{~K} 3, \mathrm{~K} 4, \mathrm{~K} 5, \mathrm{~K} 7, \mathrm{~K} 8, \mathrm{~K} 9, \mathrm{~K} 10, \mathrm{~K} 11, \mathrm{~K} 12$ \\
\hline \multirow{3}{*}{ Eğitim Durumu } & Ön lisans & 2 & $\% 15,3$ & $\mathrm{~K} 6, \mathrm{~K} 4$ \\
\cline { 2 - 5 } & Lisans & 11 & $\% 84,6$ & $\mathrm{~K} 1, \mathrm{~K} 2, \mathrm{~K} 3, \mathrm{~K} 5, \mathrm{~K} 7, \mathrm{~K} 8, \mathrm{~K} 9, \mathrm{~K} 10, \mathrm{~K} 11, \mathrm{~K} 12$ \\
\cline { 2 - 5 } & Lisansüstü & 1 & $\% 7,6$ & $\mathrm{~K} 13$ \\
\hline \multirow{2}{*}{ Ruhsatname Tipi i } & Eylemli & 13 & $\% 100,0$ & $\mathrm{~K} 1 \mathrm{ve} \mathrm{K} 13$ aras1 tüm katılımc1lar \\
\cline { 2 - 5 } & Eylemsiz & - & - & - \\
\hline
\end{tabular}

Tablo 2'de aktarıldığ üzere araştırmaya katılan turist rehberlerinin \%15,3'ü 26-35 yaş aralığında, \%38,4'ü ise 36-45 yaş, \%23,7’ü 46-55 yaş aralığındadır. Rehberlerin \%69,2 gibi büyük bir çoğunluğunun erkek olduğu görülmekte iken, kadın rehberlerin oranı da \%30,7'dir. Rehberlerin eğitim durumlarına bakıldığında \%84,6'sının lisans, \%15,3'ünün ön lisans, \%7,6'sının ise lisansüstü seviyesinde olduğu görülmektedir. Rehberlerin tamamının eylemli rehber olduğu görülmektedir

\subsection{Turist Rehberlerinin Rol ve Sorumluluklarına Yönelik Bulgular}

Katılımc1lara turist rehberlerinin Sinop ilinin turizm odaklı kalkınmasına dair rol ve sorumluluklarıyla ilgili “Bir turist rehberi olarak; turizmi kalkınmasını arttırmak adına rol ve sorumluklarını nelerdir?” sorusu yöneltilmiştir. Araştırmaya katılan turist rehberlerinin büyük bir kısmı turist rehberinin ülkeyi tanıtma, kültürel kaynakları gelecek nesillere aktarma, turistlere doğru bilgi verme gibi işlevlerinin olduğunu ifade etmişlerdir. Ayrıca turist rehberleri destinasyona yönelik olumlu imajın sağlanmasına kendilerine büyük görevler düştüğüne inanmaktadır. Bu konuya ilişkin bazı katılımcı görüşleri aşağıdaki gibidir:

"Sürdürülebilirliği tam anlamıyla destekleyip katkıda bulunmak, sadece Türkiye den turlarımıza katılan misafirlere değil, özellikle yabancı misafirlerimize ülkemiz hakkında eksiksiz ve doğru bilgi vermek, turizmin gelişmesi için yeni projeler ortaya koyup, ülkedeki turizmi geliştirmek” (Katılımc1 2)

"Ülkemizin tarihi, kültürel, doğal güzellikleri ve geleneklerini tanıtarak bir nevi kültür elçisi rolünde görevimizi icra etmektir. Turist rehberinin yaşadı̆̆ ülkeye hâkim olması gerekmektedir. Bu sebeple turist rehberi ülkenin aynasıdır. Kendisini çok iyi yetiştirmesi ve çevresindeki insanları bilinçlendirerek rol model oluşturabilir" (Katılımc1 3)

"Ülkemizi yerli ve yabancı turistlere doğru şekilde tanıtmak. Vitrin önündeki birey olarak tüm sorumluluk turist rehberindedir. Rehberin tur sirasinda her konudan doyurucu ve güncel bilgi aktarabilmesi son derece önemli bir roldür. Rehberden her konuya hâkim olması bekleniyor. Bu yüzden sürekli ögrenmeli kendini her alanda geliştirmelidir” (Katılımc1 5). 
Turist Rehberliği Dergisi (TURED) \& Yı1. 2019, Cilt. 2, Sayı 2

Journal of Tour Guiding (JOTOG) \& Year. 2019, Volume. 2, Issue. 2

Katılımcılara turist rehberlerinin Sinop ilinin turizm odaklı kalkınmasına dair rol ve sorumluluklarıyla ilgili yöneltilen bir diğer soru ise; 'Sinop'ta turizm işletmelerinin gelişimi, çevresel kaynakların korunması, yerel halk ve külttüre olan saygının arttırılması, destinasyon ekonomisinin geliştirilmesi, turizmle gelişimin sağlanması için bir turist rehberi neler yapabilir? " dur. Araştırmaya katılan turist rehberleri kamu kurumları ile iş birliği içinde olmalı ve Sinop ilinin turizme yönelik gelişiminde etkin bir rol oynamalı, söz sahibi olmalıdır. Özellikle turistlerin ihtiyaç ve beklentilerini analiz etmesi açısından aracı bir rol oynadıklarını düşünmektedirler. Bu konuya ilişkin bazı katılımcı görüşleri aşağıdaki gibidir:

"Turist rehberi her şeyden öte mesleği yaptı̆̆ her şehri sevmelidir. Gittiği ve anlattı̆̆ her şehirden övgüyle bahsetmelidir. Çeşitli kurumlarla iyi ilişkiler kurmalı, bu kurumların yarattıklart istihdamları desteklemelidir" (Katılıme1 1)

"Sivil veya kamusal kuruluşlara deneyimlerini aktararak yönelimlerinde farkındalık yaratabilir. Tabi ki soran olursa" (Katılımc1 8)

"Turizm için en büyük sorun otobüslerin park yeri sıkıntısı idi. Sinop bu konuda başarılı. Sahile güzel parklar yapıldı ve bu sorun aşılld. Sadece bu sıkıntının aşılması bile gelen turist saylsinı olumlu etkileyecektir. Sinop'a gelenler sirf cezaevini gezmek ve mantı yemek üzerine şartlanmışlar. Bunun aşılması lazım. Kalede içki olması hoş değil. Her insanın geldiği bir yerde içki satılması, içilmesi turist sayısının azalmasına sebep olacaktır. Gezilecek yerlerin tanitımının iyi yapılması gerekir. Sinop'ta turizm biraz sıkışmış. Cezaevi ile Kale arası. Hâlbuki camiler, medreseler de var. Bunlar iyi tanitılmall" (Katılıme1 11)

"Iletişime geçilen her noktada, iletişime geçilen kişilere konular hakkında mantıklı ve geçerli bilgiler sunmak, insanlarımızı daha çok bilinçlendirmek, sanırım bir turist rehberinin tüm gücü bilgisindedir bunu aktarması yeterli olacaktır” (Kat1lımc1 9)

\subsection{Sinop İlinin Turizm Odaklı Gelişiminde Zorluklar-Mevcut Durum ve Öneriler}

Katılımcılara turist rehberlerinin Sinop İlinin Turizm Odaklı Gelişiminde ZorluklarMevcut Durum ve Önerine yönelik “Tur sırasında; Turist rehberlerinin turistik bölgelerde yaşadığ zorluklar ya da sorunlar nelerdir? Ve bu sorunların turistlerin memnuniyetine etkisi ne düzeydedir? sorusu yöneltilmiştir. Araştırmaya katılan turist rehberleri grubuyla ziyaret ettikleri destinasyonlarda bazı alt yap1 ve üst yap1 sorunlarının varlığına değinmişlerdir. Özellikle park yerlerinin tur araçları için elverişsiz yapılması ve yoğun sezonlardaki yetersizliği, taşıma kapasitesinin altında konaklama imkanları, gerekli hijyen ve sanitasyon şartlarına sahip olmayan konaklama işletmeleri ve restoranların varlığı ve yerel halkın gerekli hassasiyet ve bilgiye sahip olmaması olarak ifade edilebilir. Bu konuya ilişkin bazı katılımcı görüşleri aşağıdaki gibidir:

"Gelenlerin ya da gelecek olanların bir araç ile geldikleri unutulmamall. Otobüs park edilemiyor ya da yaşlı veya engelli turistler sıkıntı çekiyor ise zamanla yöreye ilgi kayboluyor. Turistik işletmelerde hijyen.(Bilhassa Sinop için) Deniz ve güneş turizmi dlşında kültür turlarına yönelik yeterli yatak kapasitesi (deniz görmesi ya da denize uzak olması önemli değil en az 50 oda ve üzeri oteller olması, konaklama alternatifi yaratabilir bu vesile ile farkl destinasyon gruplarının ilgisi artar. Orta Karadeniz'e odakl düzenlenen seyahatlerde artış ve Doğu Karadeniz haftalık gezilerinde günübirlik geçişler konaklamalıya dönüşebilir). Halkın turizm gelirlerine iştiraki turistlere karşl sempatinin artmasina neden olur. Yerel halk unutulmamalı teşvik ve krediler ile desteklenmeli Turizm gelirlerinin yerel halkın kalkınabileceği şekilde pay edilmesi, başlı başına güçlü bir sanayi oluşturabilir. Turizmin geliştirilmesi yönünde atılacak adımlarda yörenin tarihsel ve doğal kaynaklarının deforme edilmemesi gelecek turistlerin memnuniyetini devamlı kllacaktır" (Katılımc1 8) 
Turist Rehberliği Dergisi (TURED) \& Yı1. 2019, Cilt. 2, Sayı 2

Journal of Tour Guiding (JOTOG) \& Year. 2019, Volume. 2, Issue. 2

“Otobüsümü rahat park edeceğim bir 'yalnızca tur otobüsleri için' tabelası asılı ve boș bırakılmış, uygun bir park istiyorum. Turistimle şehir içinde yürürken turistlerime sataşan, dükkâna sokmak isteyen esnaf ile karşılaşmak istemiyorum. Bu oldukça rahatsız edici. Girişlerde yeteri kadar kapı/turnike olmadığ zaman turistimin değerli vaktini kuyrukta bekleyerek geçirmek hiç iyi değil. Yürüdügümüz yerlerde çer-çöp, ezilmişs pet şişelere basarak kayıp düşenler işimizi zorlaştırıyor. Eksik uyarı levhaları, (çalışma var, kaygan zemin gibi) eksikliklerden dolayı zaman zaman sıkıntı çekiyoruz. Tehlikeli şekilde araç kullanan ve telefonda meşgul olan diğer sürücüler bizim için en büyük tehlike. Bu türlü şeyler tabi ki turistteki memnuniyet oranını düşürüyor" (Katılımc1 12).

"Bölgede birçok farklı sorunla karşılaşılsa da bunların en önemlileri, otele girişte sıkıntı yaşama (yeterli alanın olmaması, odaların çıkışının yapılmaması vs.), tur sırasında aracın arızalanması, herhangi bir ören yerine girişte problem yaşama, sinır kapısı geçişleri örnek verilebilir. Bu tarz problemler ilk aşamada turistleri çok etkilese de rehberin iyi ve anlayışlı davranışları karşısında çoğu zaman çözülüp yok denecek kadar aza indirilmesi memnuniyetlerini olumlu yöne çeker. Fakat bazı turistlerimiz kaprisli olduğu için ilk aşamada bunu gerçekleştiremeyebiliriz. Kişinin istekleri doğrultusunda normalden uzaklaşmadan memnuniyetini artırmak rehberin daha sonrasında yapacağı anlatımlarla şekillenerek güçlenebilir" (Katılımc1 6).

Katılımcılara turist rehberlerinin Sinop İlinin Turizm Odaklı Gelişiminde ZorluklarMevcut Durum ve Önerine yönelik "Sinop ili turistlerin beklentilerine cevap verebilecek nitelikte bir destinasyon mudur? Turist de bölgeye gerekli ekonomik katkıyı sağllyor mu?” sorusu yöneltilmiştir. Katılımcılar Sinop'un turistler için cazip bir destinasyon olduğu, ancak belli başlı çekiciliklerin dışında farklı nitelikleriyle de tanıtılması gerekliliğini ifade etmişlerdir. Konuya ilişkin katılımcıların görüşleri aşağıdaki gibidir,

"Sinop, Cezaevi, tarihi camileri, Hamsilos Koyu ve Erfelek SSelalesi gibi destinasyonlartyla beklentilere cevap verebiliyor. Ama bunlar arttirlmalıdır. Sinop ilimizin gerekli katkıyı alabilmesi için yöresel ürünleri ortaya çıkarması lazım. Sadece mantı ve kotra ile gerekli katkı gelmez" (Kat1lımc1 7).

"Sinop güzel bir destinasyon, fakat Sinop, cezaevinden ve mantıdan ibaret değildir. Destinasyonları kitaplara değil insanların beynine (acenta ve rehberlerin) yerleştirmek lazım. İlgili kamu kurumları bu kişilere info vermesi Sinop'a davet ederek diğer destinasyonların turlara ilave edilmesi hatta Sinop'ta konaklaması. Oteller yetersiz ve çok pahalı hizmet yetersiz. Belli kesim Sinop'un turizm kaderiyle oynuyor" (Kat1lımc1 3).

"Sinop'ta turizmin gelişmesi için bazı yapılması gereken hususlar bulunmaktadır. Kamu kurum ve kuruluşları öncelik olarak altyapı çalışmasını hazırlaması gerekmektedir. Ancak bir çok tarihi ve doğal güzelliklere sahip olmasına karşın yeterince özen gösterilmiyor. Erfelek Şelalesi, Sinop Tarihi Cezaevi, plajın turistik ihtiyaçlara cevap verebilmesi turizmin gelişmesi açısından önemli. Havayolu şirketlerinin uçuşu arttırması, Türkiye'nin en kuzey noktasının pazarlanması ve tanıtımının sağlıklı bir şekilde yürütülmesi mutlaka şart" (Katılımc1 $5)$.

Katılımcılara turist rehberlerinin Sinop İlinin Turizm Odaklı Gelişiminde ZorluklarMevcut Durum ve Önerine yönelik "Sinop ilinin turizmde gelişebilmesi adına Kamu kurumları ya da özel sektör bu konuda neler yapmalıdır? sorusu yöneltilmiştir. Turist rehberleri; Sinop ilinin hem özel sektör hem de kamu kurumlarının işbirliği ile kalkınabileceğini düşünmektedir. Öneriler arasında; Yat ve kruvaziyer turizmi, ekoturizm ya da agro-turizm gibi turizm türlerinin ve aktivitelerinin geliștirilmesi, kültür turizmi rotalarının Sinop konaklamalı gerçekleştirilmesi, yerel halkın turizmden daha fazla pay alması ve daha korunabilen deniz 
Turist Rehberliği Dergisi (TURED) \& Y11. 2019, Cilt. 2, Sayı 2

Journal of Tour Guiding (JOTOG) \& Year. 2019, Volume. 2, Issue. 2

alanlarının oluşturulması yer almaktadır. Konuya ilişkin katılımcıların görüşleri aşağıdaki gibidir:

"Tur operatörlerini ilinize getiriniz. (Davet etmeyiniz, gerekirse gidip kendiniz getiriniz) Geldiklerinde onlara özel misafir mualemesi yapmayını. Onun yerine, Sinop'u da tur programlarina kattıklari takdirde, turistlerinin neler yapabilecegini gösteriniz. Bir veya birkaç festival düzenleyiniz. Mesela portakal çiçeği, ot festivali, badem çiçeği, lavanta hasadı festivallerini inceleyiniz. Bu şekilde ara destinasyon olmaktan çıkıp ana destinasyon olursunuz. Takvimi belli bazı yerel gösteriler yapınız. Sinop'a özgü halk oyunları olabilir, yemek yarışması olabilir, denizcilikle alakalı bir şey olabilir. Üzerine düsünmek gerekir. Ele ele vererek sosyal medyada bir veya birkaç sayfa açarak Türkçe, Ingilizce, Arapça (hangi turistin ilgisini çekmek isterseniz ona göre dil seçiniz) paylaşımlar yapınız (gezmek için bahane arayan,para harcamaya hazır Kuzey Avrupa ülkelerini tavsiye ederim)" (Kat1lımc1 13).

"Büyük şehirlerdeki belli başl operatör acentalarla yapılan çalışmalar (ziyaret veya bölge de ağırlama) ile aktarllabilir, görüşleri alınabilir. Yabancı operatörler Rusya, Ukrayna, Fransa, Ingiltere gibi ülkelerde fuar tanitımı. (Çok kapsamlı alanlara değil $5 \mathrm{~m}^{2}$ lik 1000 euro veya 800 paundluk stantlar veya Turizm Bakanlığının ücretsiz stantlarında ama iyi derecede yabancı dil bilen en fazla 2-3 kişinin gelenleri bilgilendireceği fuar çalışması) yerel acenta temsilcileri de orada kart verebilir. Bunlar motive etmek adına yol ve otel paraların kendileri karşılamak üzere standa fuar süresince davet edilebilir.). Yurt dışı fuarlarda bölge tanıtımları (dünya bankası kredi veriyor) (misalen.. Leicester yakınlarından Oakham da her yll 17 ăgustosta başlayan Bird Watching Fair (Kuş Gözlem Fuarl) Naturetreck, Bird Quest, Bird Finders gibi çok sayıda tur operatörleri fuarda stand altyor çok ilgi çekeceğinden emin olabilirsiniz. Türkiye'de de Trakuş gibi organizasyonların dikkatlerini çekebilir yardımları alınabilir)" (Kat1lımc1 6).

"Yeni otel sahası açmak yerine Akliman gibi yerlerde ev pansiyonlarına uygun kobi kredisi ve sektörel ĕgitim verilmesini sağlayarak oda sayılarını artırabilir, görsel handikapları düzeltilebilir. Foseptik yerine denizi kirletmeyecek şekilde alt yapt sorunları giderilebilir. Sadece tersaneye değil limana da otobüslerin trafik slkışıklı̆̆ına meyil vermeden daha rahat manevra yapabileceği bir farklı arter açabilir. Bu arterin bir uzantısı Karakum ve Tabyalara ulaşabilir. Acentalar Sinop'tan başlayıp Amasra'da biten otel konaklamalı mavi turlar düzenleyebilir. Bir köyü pilot seçerek temiz şirin ekolojik tarım ve hayvancıllk uygulamaları yapan turistlerin gelerek yöre insanını tanıyabileceği alış veriş yapabileceği yöresel mutfağ tadabileceği örnek köy veya marka köy yaratabilir. Yelken Kulübü Türkiye genelinde yelkenciliği ve rüzgâr sörfünü gençlere ve deniz tutkunlarına ögrretebileceği bir yelken okulu organize edebilir. Ülkesel ve uluslararası müsabakalar düzenleyebilir. Ulaştırma Bakanlı̆̆ vizesiz Sinop -Yalta seferlerini yeniden aktif hale getirebilir. Sarı kum da kuş gözlem kuleleri ile karavan-çadır kamping alanı yapılabilir (ortak mutfă̆g ve wo ile duş imkânı sunan, karavanciların elektrik prizi imkânı da alabileceği, güvenlikli, yalnı mangal kısıtlanmalı, sportif amaçlı bir sahadan bahsetmekteyim. Doğa sporları odakl yerli yabancı acentalara tanıtım yapılabilir. Yürüyüş, dăg bisikleti rotaları ayrıca kuş gözlemciler için muhtelif teraslar hizmete sokulabilir)" (Kat1lımc1 2).

\section{Sonuç ve Öneriler}

Türkiye'nin bölgeler arası dengeli gelişimini sağlamak amacıyla oluşturulan kalkınma planları, tarımdan, politikaya pek çok konuyu kapsamaktadır. Özellikle gelir arttıran, uygulamaya dönük alanlar kapsamında görülen turizm kalkınmada öncelikli konulardan biri olarak kabul edilmektedir. Tarım ve sanayinin olmadığı bölgelerde istihdam sağlayan, gelişimi güçlendirebilecek bir kavram olan turizm kalkınmaya ivme kazandırabilmekte ve bölgesel 
gelişimin kilit kavramlarından biri olarak kabul edilebilmektedir. $\mathrm{Bu}$ gelişimin tetikleyicilerinden biri de turizm paydaşlarıdır. Turizme yön veren, gidişatını ve işleyişini etkileyen, toplumsal değişimde büyük bir role sahip olan turizm paydaşları bir bölgenin turizme dönük kalkınmasında önemli bir konumdadır. Bu araştırmada ise turizm paydaşlarından biri olan turist rehberlerinin rol ve sorumlulukları incelenmiştir.

Araştırmanın sonuçlarına göre; turist rehberlerinin yaş ortalamasının büyük bir kısmının orta yaş ve üzeri olduğu görülmektedir. Kadın rehberin erkek rehberlere göre daha az bir sayıya sahip olması da bölgede aktif olarak çalışan kadın rehberlerin mevcut durumunu ifade edebilir. Eğitim durumlarına bakıldığında ise büyük bir kısmının lisans mezunu olması umut vaat edici niteliktedir. Ayrıca araştırmaya katılan rehberlerin tamamının eylemli olması da sektör de çalışan rehber sayısını gösterir niteliktedir.

Turist rehberleri turizme yönelik kalkınmada yönlendirici ve aracı bir rol oynadığını düşünmektedir. Ziyaret ettikleri destinasyona dair olumlu imajın oluşmasında turist rehberlerinin etkisi farklı çalışmalarda da dile getirilmiştir (Batman, 2003; Çokişler ve Öter, 2014: 196). Turist rehberleri ülkenin imajını güçlendirmesinin yanında; bilgi verdiği kültürü, doğal ve tarihi mirası korumak ve koruma bilincini öğretmekle de görevlidir. Bu rehberlerin öğretici ve yol gösterici rollerinden birini ifade etmektedir. Katılımcıların görüşmeler sırasında dile getirdikleri bir diğer husus ise turist rehberlerinin elçi ve aktarıcı rolleridir. Bu işlevleriyle rehberler destinasyonun tanıtımını gerçekleştirirken; kültürünü, doğal ve tarihi kaynakları, gelenek ve göreneklerini de turistlere sevdirmektedir.

Turist rehberlerinin Sinop turizmiyle ilgili olumlu görüşlere sahip olmalarına karşın bazı eksiklerin de tamamlanması gerektiğine vurgu yapmışlardır. Park yerleri, alt ve üst yapı sorunları, bazı tarihi mekanlarda alkol satışı, enformasyon memurlarının yeterli bilgi ve donanıma sahip olmaması olarak ifade edilebilir. Bu eksikliklerin giderilmesi içinde rehberler kamu kurumları ve özel sektörün sıkı işbirliğini savunmaktadır. Sinop gibi küçük ama fazla turist çeken şehirlerin farklı kurumların işbirliğine imkân tanıması şehrin hızlı kalkınmasına katkı sağlayabilir.

Sinop kentinin turizmde büyük ivme kazandığını ifade etmek mümkündür. Özellikle son yıllarda sayısı bir milyona yaklaşan ziyaretçi sayısıyla (Sinop İl Kültür ve Turizm Müdürlüğü, 2018) Karadenizin en yoğun turist ağırlayan destinasyonları arasında yer almaktadır. Bununla birlikte turist rehberleri bazı sorunların varlığına değinmiştir. Özellikle altyapının yetersizliği, konaklama işletmelerinin nitelikli hizmet sunmadaki eksiklikleri, yiyecek-içecek işletmelerinin gıda ve restoran hijyenine gerekli özeni göstermemesi, yerel halkın uzun yıllardan beri turizmle iç içe olmalarına karşın hala turizmi yeterince benimsememesi konuları turist rehberlerinin tur sırasında karşılaştığı sorunlardan bazılardır. Bir şehrin turizmle gelişmesi sorunlarının tespit edilip giderilmesi ile mümkündür. Kamu kurumları, otel, yiyecek-içecek ve rekreasyon işletmeleri durumun farkına varıp en kısa zamanda farklı stratejilerle turizmi geliştirmeye devam etmelidir.

Turist rehberleri Sinop şehrinin turistik bir çekiciliğe sahip olduğunu ancak klasik özelliklerinin de dışında festivaller, farklı tur rotaları, etkinlikler, fuarlar gibi bölgesel kalkınmaya imkan tanıyacak aktivitelerle zenginleştirmeleri gerektiğini düşünmektedirler. Sinop destinasyonunun en temel çekim kaynakları yanında yeni festivaller, gösteriler, sık güncellenen sosyal medya hesapları ile Sinop kenti daha büyük adımlarla ilerleyebilecektir. $\mathrm{Bu}$ noktada; büyük tur operatörlerinin, kurvaziyer turizmiyle ilgilenen acentaların da programlarına dâhil olabilmek adına Sinop şehrinde ağırlanması, rotalarına eklenmesi için Sinop'un özgün nitelikleri tanıtılması mümkün olabilir. Su sporlarının merkezi olabilecek bir şehir konumunda olan Sinop için bu anlamda ilgili birimlerle görüşülüp farklı planlamalar ve projeler 
gerçekleştirilebilir. Farklı turizm aktiviteleri ile Sinop turizminin güçlendirilmesi, Sinop şehrini daha güçlü ve önemli bir konuma getireceği düşünülmektedir. Özellikle yöresel ürünlere vurgu yapan, doğa temelli, kültürel kaynakların ön plana çıkarıldığı eko-çiftliklerin oluşturulması Sinop için önemli bir adım olabilir. Ayrıca bir gastronomi köyü oluşturularak turizmin popüler konusu ile gastronomiyle de turistlerin ilgisi çekilebilir. Turizmin yerel halk ile güçlenmesi gerektiğine inanan turist rehberleri Sinop gibi doğal ve kültürel değerlerini koruma çabası içinde olan bir şehrin yine kendi kaynakları ile kalkınması gerektiğine inanmaktadırlar. Bu konuda nitelikli kamu destekleriyle açılan pansiyonlarla hem yerel halk kalkınacak hem de ev pansiyonculuğu ile turizmde sürdürülebilir gelişim sağlanacaktır.

Kalkınma süreci sürdürülebilirlikle beraber anılmalıdır. Turist rehberleri sürdürülebilirliğin temel amaçları arasında yer alan doğal kaynakların korunması ilkesine Sinop'ta önem verildiğine dair şüpheleri bulunmaktadır. Temiz bir çevre, korunan doğal alanlar, maviyle denizin buluştuğu hijyenik plajlar hemen hemen tüm turistlerin beklentiler arasındadır. Bu açıdan; Sinop şehrinin altyapı eksikliklerinin tespit edilip, düzenli kontroller ile turistlerin hizmetine daha nitelikli bir biçimde sunulması gerekmektedir.

Sinop şehri eşine az rastlanır doğal alanlara, milli parklar, korunabilir sahalara sahiptir. $\mathrm{Bu}$ nitelikleri ile turizmin vazgeçilmez bir parçası olmaya aday bir şehirdir. Bilinmektedir ki bir şehri rekabet edebilir bir destinasyon konumuna getirmek için alt ve üst yapı çalışmaları, farklı paydaşların önerilerinin dikkate alınması, nitelikli ve üzerinde çalışılmış planlar gerekmektedir ki bu süreç birkaç kişi ile başarılabilecek bir konu değildir. Sinop kentinin turistlerin ziyaretlerine sebep olan kaynakları yanında keşfedilmemiş turizm aktiviteleri, doğal ve kültürel alanları mevcuttur. Bu sahaların uygun kişi ve kurumlarca turizme açılıp, farklı turizm türleri ile entegrasyonun sağlanması Sinop turizmini daha da güçlendirebilir, kalış sürelerini arttırabilir. Turist rehberleri bir şehrin en iyi gözlem yapanları arasındadır. Turistlere zengin bilgi ve deneyimini aktarıken; eksikliklerin farkında olarak, farklı destinasyonlarla karşılaştırarak aktarır ve bu durum onun bakış açısında büyük farklılıklar oluşturur. Bu açıdan turist rehberlerinin Sinop kentine yönelik algı ve rolleri turizm açısından önemli bir konu olarak kabul edilebilir. Ancak çalışma sadece Sinop şehrinin turizm odaklı kalkınmasında turist rehberlerinin görüşlerini ve rollerini incelemektedir. $\mathrm{Bu}$ kapsamda farklı bölgelerin, destinasyonların ele alınması, farklı araştırma yöntemleri ile incelenmesi önerilebilir.

\section{Kaynakça}

Ak, S., Kargiglioğlu, Ş. ve Erkol Bayram, G. (2019), Turist Rehberliği Mesleği, B. Zengin, G. Erkol Bayram ve O. Batman (Ed.) Turist Rehberliği Mesleği (Dünü-Bugünü-Yarını) Detay Yayıncilık, Ankara.

Aktaş, S. ve Batman, O. (2010). Efsanelerin Turistik Çekicilik Üzerine Etkileri: Profesyonel Turist Rehberlerine Yönelik Bir Araştırma. e-Journal of New World Sciences Academy, 5(4), 365-395.

Ap, J. ve Wong, K. K. (2001). Case Study on Tour Guiding: Professionalism, Issues and Problems. Tourism Management, 22, 551-563.

Batman, O. (2003), Türkiye'deki Profesyonel Turist Rehberlerinin Mesleki Sorunlarına Yönelik Bir Araştırma, Bilgi Dergisi, 2003/2, 117-134.

Çokişler, N. ve Öter, Z. (2014), Türkiye'de Turist Rehberliği Eğitimi Veren Eğitim Kurumlarına Yönelik Bir Araştırma, 15. Ulusal Turizm Kongresi, 13-16 Kasım, Ankara: Gazi Üniversitesi, Bildiriler Kitab1, 196-209.

Çubuk, M. (1996). Sürdürülebilir Turizm, Turizm Planlamasına Ekolojik Yaklaşım. Türkiye'de 19. Dünya Şehircilik Günü Kolokyumu. MSÜ. İstanbul. 
Eker, N. ve Zengin, B. (2016). Turist Rehberliği Eğitiminin Değerlendirilmesi: Profesyonel Turist Rehberleri Üzerine Bir Uygulama. Ë̆itim ve Öğretim Araştırmaları Dergisi, 5(4), 65 74.

Emeksiz, M. (2007). Küçük Otel İşletmeleri ve Çevre Yönetimi, Balıkesir Üniversitesi Sosyal Bilimler Enstitüsü Dergisi, 10(18), 141-156.

Erkol Bayram, G. (2017). Motivasyonun Demografik ve Mesleki Özelliklere Göre Farklılaşması: Turist Rehberleri Üzerine Bir Araştırma. Journal of Yaşar University, 12(48), 257-271.

Erkol Bayram, G., Bayram, A.T., Altunöz, O. (2016), Sürdürülebilir Kalkınma için Turizm: Şanlıurfa' da Bulunan Sivil Toplum Kuruluşlarının Görüşleri, ÜNIDAP Bölgesel Kalkınma Konferans1, 28-30 Eylül, Muş.

Ham, S. ve Weiler, B. (2002). Toward a Theory of Quality in Cruise-Based Interpretive Guiding, Journal of Interpretation Research, 7(2), 29-49.

Han, E. ve Kaya, A. A. (2008). Kalkınma Ekonomisi Teori ve Politika, Düzeltilmiş ve Gözden Geçirilmiş 6. Baskı, Ankara: Nobel Yayıncılık.

Hughes, K. (1991). Tourist Satisfaction: A Guided "Cultural" Tour in North Queensland, Australian Psychologist, 26, 166-172.

Kaypak, Ş. (2012). Ekolojik Turizm ve Sürdürülebilir Kırsal Kalkınma. KMÜ Sosyal ve Ekonomik Araştırmalar Dergisi, 14(22), 11-29.

Keskin, A. ve Cansiz, H. (2010). Tourism, Turkey and Economic Development, Atatürk Üniversitesi İktisadi ve İdari Bilimler Dergisi, 24(4), 23-45.

Köroğlu, Ö. (2013). Turist Rehberlerinin İş Yaşamındaki Rolleri Üzerine Kavramsal Bir Değerlendirme. Pamukkale Üniversitesi Sosyal Bilimler Enstitüsü Dergisi, 16, 2013, 91-112.

Küçük, M. ve Güneş, G. (2013). Kızılcahamam'da Turizm ve Yerel Kalkınma. (05-08 Aralık 2013), 14. Ulusal Turizm Kongresi, Kayseri, 196-215.

Künü, S. ve Hopoğlu, S. (2015). Turizm ve Sürdürülebilir Büyüme: Eleştirel Bir Yaklaşım, Doğu Karadeniz Bölgesi Sürdürülebilir Turizm Kongresi, 14-15 Mayıs 2015, Gümüşhane, 103-111.

Látková, P., Jordan, E., Vogt, C., Everette, M. ve Aquino, C. (2017). Tour Guides' Roles and Their Perceptions of Tourism Development in Cuba, Tourism Planning \& Development, 117.

Leclerc, D. ve Martin, J. N. (2004). Tour Guide Communication Competence: French, German and American Tourists' Perceptions, International Journal of Intercultural Relations, 28(34), 181-200.

Pond, K. L. (1993). The Professional Guide: Dynamics of Tour Guiding. New York: Van Nostrand Reinhold Company.

Sinop İl Kültür ve Turizm Müdürlüğü (2018). Turizm İstatistikleri, http://www.sinopkulturturizm.gov.tr/TR-74927/istatistikler.html (Erişim Tarihi: 28.06.2019).

Strauss, A. ve Corbin, J. M. (1990). Basics of Qualitative Research: Grounded Theory Procedures and Techniques. Thousand Oaks, CA, US: Sage Publications, Inc.

Şanlı, C. ve Eksi, N. (2005). Bölgelerarası Dengesizliğe İktisadi Gelişme Teorileri Açısından Bir Yaklaşım, İstanbul: Arıkan Yayıncılık.

Şenel, G. (2011). Stres Faktörlerinin İş Motivasyonuna Etkisi: Turist Rehberleri Üzerine Bir Uygulama (Yayınlanmamış Yüksek Lisans Tezi). Balıkesir Üniversitesi, Sosyal Bilimler Enstitüsü, Balıkesir.

Tekbalkan, M. (2017). Turizmin Bölgesel Kalkınmaya Etkisi Üzerine Bir Alan Araştırması: Samsun - Havza Örneği. Beykoz Akademi Dergisi, 5(1), 35-52. 
Turist Rehberliği Dergisi (TURED) \& Yıl. 2019, Cilt. 2, Sayı. 2

Journal of Tour Guiding (JOTOG) \& Year. 2019, Volume. 2, Issue. 2

Türnüklü, A. (2000). Eğitim Bilim Araştırmalarında Etkin Olarak Kullanılabilecek Nitel Bir Araştırma Tekniği: Görüşme, Kuram ve Uygulamada Eğitim Yönetimi, 6 (24), 543- 559.

Yıkmaz, R.F. (2011). Sürdürülebilir Kalkınmanın Ölçülmesi ve Türkiye İçin Yöntem Geliştirilmesi, (Uzmanlık Tezi), T.C. Başbakanlık Devlet Planlama Teşkilatı Müsteşarlığı Sosyal Sektörler ve Koordinasyon Genel Müdürlüğü, Ankara.

Yıldırım, A. ve Şimşek, H. (2005). Sosyal Bilimlerde Nitel Araştırma Yöntemleri. Ankara: Seçkin Yayınları.

Yıldız, R., Kuşluvan, S. ve Şenyurt, Y. (1997). Turist Rehberliği Öğretiminde Yeni Bir Model: Nevşsehir Turist Rehberliği Bölümü Programı ve Değerlendirilmesi, Erciyes Üniversitesi Nevşehir Turizm İşletmeciliği ve Otelcilik Yüksekokulu Hafta Sonu Semineri IV, 9-14.

6326 Say1lı Turist Rehberliği Meslek Kanunu (2012). 22 Haziran 2012 Tarih ve 28331 Sayılı Resmi Gazete (Erişim Tarihi: 28.06.2019). 